\title{
MARKETING
}

RECEIVED:

19 April 2021

ACCEPTED:

19 May 2021

RELEASED:

20 June 2021
UDC 339.138

DOI 10.26661/2522-1566/2021-1/16-06

\section{USE OF SOCIAL MEDIA MARKETING IN SMEs: DRIVING FACTORS AND IMPACTS}

\author{
Iva Nurdiana Nurfarida* \\ Universitas Negeri Malang \\ Indonesia \\ ORCID ID: 0000-0002-8147-4851
}

\author{
Sudarmiatin \\ Universitas Negeri Malang \\ Indonesia \\ ORCID ID: 0000-0003-1411-8870
}

*Corresponding author email: iva.nurdiana.2004139@students.um.ac.id

\begin{abstract}
This study is aimed at exploring the factors that encourage the use of social media marketing in Café \& Resto sector, as well as to find out its benefits. Using a descriptive exploratory research approach, an online survey was conducted at Café \& Resto sector in Malang City Indonesia. The samples were selected using convenience sampling technique, the respondents were asked to fill out a Google Form which was sent to their social media addresses. A total of 300 cafes and restaurants have been contacted through their social media accounts, which corresponded to 106 respondents. The results showed that the main factors considered by Café \& Resto companies in choosing social media marketing were to introduce products to consumers, as the majority of consumers were social media users, to increase the popularity of businesses, and to share information with consumers. Additional factors are the encouragement of competitors who also use social media, and low cost. The main benefits obtained from the use of social media marketing are increased communication with customers, brand awareness and brand image, new customer acquisition, savings in promotional costs, increased sales, and ability to manage dissatisfaction (customer service and feedback). This study has limitations, the number of respondents involved is limited, further research is needed with a wider sample. In addition, further research can be developed by testing the effectiveness of using each social media channel, because each social media channel has different user characteristics and goals.
\end{abstract}

Keywords: social media marketing, customer communication, brand awareness.

JEL Classification: L1, M31.

\section{INTRODUCTION}

The development of technology in recent years has led to changes in consumer purchasing behavior and marketing strategies adopted by business firms. The use of technology such as social media makes it easier for consumers to find information about products or services needed for purchasing decisions (Chen, Lu and Wang, 2017). In the business field, the information technology revolution has led to a change in marketing strategies from conventional approach to the concept of social media marketing.

The development of social media causes changes in communication patterns and affects 
Nurfarida, I. N. and Sudarmiatin (2021), "Use of social media marketing in SMEs: driving factors and impacts", Management and entrepreneurship: trends of development, 2(16), pp. 70-81. Available at: https://doi.org/10.26661/2522-1566/2021-1/16-06.

marketing communication (Hutter et al., 2013). This cannot be avoided as social media can create effective communication and interaction. Social media encourage companies to look for effective ways to improve customer relationships (Quinn, 2016), and customer engagement (Kozinets et al., 2010). Social media are an important part of marketing activities for they provide benefits and opportunities to develop ways of conducting marketing communications (Kaplan and Haenlein, 2010).

The development of information technology has also been accompanied by changes in people's lifestyles, one of which being the habit of gathering in cafes or restaurants. This condition encourages the growth of the Café \& Resto business with various innovations, offering not only food and drinks but also a comfortable place and a great view to take photos. According to the Indonesian Café and Restaurant Entrepreneurs Association (Apkrindo) in East Java, the Café \& Resto business in East Java Indonesia has grown by 18\% (Wahyudi, 2019). According to the Baseline Economic Survey conducted by Bank Indonesia Malang, the situation is similar in Malang City. For 2-3 years, the Café \& Resto business has grown in Malang city, although it has not gone along with business sustainability (Malangtimes, 2019).

Nowadays, finding a café or restaurant is not hard. We can find all the information needed from social media, starting from the uniqueness, location, and price. Café \& Resto sector generally has youth and adult segments. Thus, social networks are the right promotion medium either to introduce products or services or to popularize their business.

Previous studies have recognized that social media contribute to marketing and sales activities (Marshall et al., 2012; Guesalaga, 2016), increase brand awareness (Ardiansyah and Sarwoko, 2020), build customer relationships (Quinn, 2016), and create value (Garrido-Moreno et al., 2020). However, in the context of SMEs, the challenge is to measure the benefits of using social media (Schultz and Peltier, 2013). Furthermore, there is still limited knowledge about the motives of using social media by SMEs in their marketing activities.

\section{LITERATURE REVIEW}

\section{Social media marketing}

Social media marketing is marketing and customer management activity using social media (Buttle and Maklan, 2019). Social media marketing is part of digital marketing to facilitate customer interaction with companies and brands in social networks (Hutter et al., 2013; Chaffey, 2015). It is aimed at encouraging consumer interest in a brand (Magasic, 2016), obtaining customer input, and improving customer experience (Jin, Muqaddam and Ryu, 2019). Social networking sites have become platforms that allow interaction between consumers and a brand (Tsai and Men, 2013).

According to Tuten (2020), social media activities can be classified into four groups based on their objectives: social community, commerce, entertainment, and publishing. A social community is a social media activity that focuses on the relationship between users, resulting in two-way communication, conversion, collaboration, and sharing of experience. The social communities include Twitter, Facebook, Instagram, Linkedin, and Reddit (Tuten, 2020). This study has focused on discussing the use of social media as a means of marketing activities. The presence of social media initially had a feature to share experiences and content among users (Ismail, 2017) by displaying photos or videos. However, in its development, social media can also be used by businesses for sharing information about products or brands, promotion, and communication with customers.

\section{The motive for the use of social media marketing}

Social media are new communication medium that encourages interaction (Brogan, 2010), and has become a new alternative for communicating with customers. Tsai and Men (2013) argue 
that social media have evolved into a forum for customers to engage with brands, which has an effect on purchasing decision (Elwalda and Lu, 2016). Social networking has the advantage of being able to communicate with consumers and handle customer service problems efficiently and effectively.

Tsimonis and Dimitriadis (2014) state that the basic motivations for using social media are increasing polarity, competitor presence, and reducing cost. The expected objectives are to interact with customers, to create relationships with customers, to raise brand awareness, and to promote products. Meanwhile, Tsai and Men (2013) explain that relationship motives and encouragement of consumer involvement are important factors in the use of social media. The previous studies have classified social media marketing activities as presented in table 1 below:

Table 1

\section{Motivation to use social media}

\begin{tabular}{|c|c|}
\hline Motivation to use social media & Authors \\
\hline $\begin{array}{l}\text { Understanding the customer; approaching the customer; } \\
\text { needs discovery; presentation; close; service and follow-up }\end{array}$ & Andzulis, Panagopoulos and Rapp (2012) \\
\hline \multirow{2}{*}{$\begin{array}{l}\text { Entertainment; interaction; trendiness; customization; } \\
\text { perceived risk }\end{array}$} & Kim and Ko (2012); \\
\hline & Seo and Park (2018); Godey et al. (2016) \\
\hline $\begin{array}{l}\text { Entertainment; social integration; personal identity; } \\
\text { information; empowerment; remuneration }\end{array}$ & Tsai and Men (2013) \\
\hline $\begin{array}{l}\text { Personal factor: competence and individual commitment to } \\
\text { the use of social media }\end{array}$ & \multirow{2}{*}{ Guesalaga (2016) } \\
\hline $\begin{array}{l}\text { Situation factor: competence and organizational } \\
\text { commitment to social media use, customer engagement. }\end{array}$ & \\
\hline $\begin{array}{l}\text { End user; organizational; technological; management } \\
\text { business environment }\end{array}$ & Dahnil et al. (2014) \\
\hline $\begin{array}{l}\text { Market research and feedback generation; publicity, } \\
\text { branding, and reputation management; business } \\
\text { networking; customer service and customer relationship } \\
\text { management }\end{array}$ & Thoring (2011) \\
\hline $\begin{array}{l}\text { Popularity; presence of competitors; cost reduction; } \\
\text { technology advances; promotion }\end{array}$ & $\begin{array}{l}\text { Tsimonis and Dimitriadis (2014); Durkin, } \\
\text { McGowan and McKeown (2013), Christina, } \\
\text { Fenni and Roselina (2019) }\end{array}$ \\
\hline
\end{tabular}

\section{Source: Formed by authors}

Based on the literature review, the considerations for adopting social media marketing can be grouped into two categories: internal and external factors. Internal factors include promotion (publicity, branding, and reputation), customer involvement, understanding customers, interaction, service and follow-up, cost reduction, popularity, and customer relationship management. External factors include technological developments (trendiness), competition, and consumers or end-users. 
Nurfarida, I. N. and Sudarmiatin (2021), "Use of social media marketing in SMEs: driving factors and impacts", Management and entrepreneurship: trends of development, 2(16), pp. 70-81. Available at: https://doi.org/10.26661/2522-1566/2021-1/16-06.

\section{Benefits of social media marketing}

Social media have evolved into a forum for customers to engage with brands (Tsai and Men, 2013). Thus, purchasing decisions are significantly influenced by this relationship between customers and brands (Elwalda and Lu, 2016). Binienda (2017) explains that social media content can persuade consumers to make purchases.

Table 2

\section{Benefit of social media marketing}

\begin{tabular}{|c|c|}
\hline Benefit of social media & Authors \\
\hline Brand awareness, brand loyalty & $\begin{array}{l}\text { Barreda et al. (2015); Hutter et al. (2013); Tsimonis and } \\
\text { Dimitriadis (2014); Ismail (2017); Lim, Chung and } \\
\text { Weaver (2012); Bilgin (2018) }\end{array}$ \\
\hline Purchase intention and purchase decision & $\begin{array}{l}\text { Hutter et al. (2013); Hudson and Thal (2013); } \\
\text { Ardiansyah and Sarwoko (2020); Goodrich and De } \\
\text { Mooij (2014); Lin (2013); Jalilvand and Samiei (2012); } \\
\text { Guesalaga (2016); Marshall et al. (2012); Kristina and } \\
\text { Sugiarto (2020) }\end{array}$ \\
\hline $\begin{array}{l}\text { Customer relationship; brand awareness; } \\
\text { customer engagement; increased sales; new } \\
\text { customer }\end{array}$ & Tsimonis and Dimitriadis (2014) \\
\hline $\begin{array}{l}\text { Brand equity (brand awareness \& brand image); } \\
\text { brand attitude }\end{array}$ & $\begin{array}{l}\text { Langaro, Rita and de Fátima Salgueiro (2018); Seo and } \\
\text { Park (2018); Godey et al. (2016) }\end{array}$ \\
\hline
\end{tabular}

\section{Source: Formed by authors}

Several researchers have conducted studies related to the expected goals of using social media marketing for their business as presented in table 2 .

\section{PAPER OBJECTIVE}

This study was conducted to investigate the factors that encourage SMEs to adopt social media marketing and to find out its benefit.

\section{METHODOLOGY}

The study used an exploratory descriptive approach to consider the factors that drive media use in business and the expected benefits of using social media. An exploratory research is useful in situations where available information is limited and researchers want to have the flexibility to explore the research field (Cooper, Schindler and Sun, 2006). The survey was conducted in Café \& Resto sector in Malang City, to explore the driving factors for the use of social media as well as the benefits obtained. In this study, data were collected online, making use of social media addresses. Social media accounts of 300 cafes and restaurants were contacted. After a month, 106 responses were obtained. 
The research instrument used in this study was adapted from a previous study in the form of closed and open questions, where a manager or an owner of a café or a restaurant needs to explain his / her consideration in using social media and analyze the benefits of using them.

\section{RESULT AND DISCUSSION}

\section{Types of Social Media Used}

Respondents were asked about the types of social media used in their marketing activities. The used social media are generalized in Table 3.

Table 3

Used Social Media

\begin{tabular}{|c|c|}
\hline Social Media & Percentage \\
\hline Facebook & $99 \%$ \\
\hline Instagram & $100 \%$ \\
\hline Twitter & $78 \%$ \\
\hline Lain-lain & $45 \%$ \\
\hline
\end{tabular}

\section{Source: Formed by authors}

Social media such as Instagram and Facebook are the types most chosen by Café \& Resto sector as marketing media. This fact can be explained by high popularity of Facebook and Instagram. Moreover, they can embrace various segments of users.

\section{Motives for the Use of Social Media Marketing}

Respondents were asked about the characteristics of the social media beneficial for their business (Table 4). It is an interesting finding that Café \& Resto companies use social media if they want to introduce the brand (95\%). Furthermore, they also use social media since most of the intended consumers are social media users $(92 \%)$. Cafés and restaurants currently do not only serve food and drinks, but also provide places for entertainment, comfortable venue facilities, and attractive place designs for taking photos. Social media are used to make the characteristics of cafés and restaurants recognizable for potential consumers. Social media are the most appropriate choice, for information can be spread among their users, attracting more information accompanied by interesting photos. Café \& Resto has a target market and segment among teenagers who are identified as social media users. Social media are used to introduce products/services to their users. This finding supports the previous study that concludes that the function of social media marketing is to support promotional activities via social media (Tsai and Men, 2013). 
Nurfarida, I. N. and Sudarmiatin (2021), "Use of social media marketing in SMEs: driving factors and impacts", Management and entrepreneurship: trends of development, 2(16), pp. 70-81. Available at: https://doi.org/10.26661/2522-1566/2021-1/16-06.

Table 4

Motive using Social Media Marketing

\begin{tabular}{lc}
\hline \multicolumn{1}{c}{ Motive using social media } & Percentage \\
\hline Popularity & $73 \%$ \\
Introduce new product/service & $95 \%$ \\
Information & $61 \%$ \\
Competitors use social media & $45 \%$ \\
Consumers are social media users & $92 \%$ \\
Low cost & $45 \%$ \\
\hline
\end{tabular}

\section{Source: Formed by authors}

Another factor that encourages the use of social media in marketing activities is to popularize business and to provide information about the business to consumers. Café \& Resto companies owners use social media in their marketing activities because competitors also use those. Another reason is the low cost of such activities. However, this is not the main consideration in using social media marketing, since only $45 \%$ of respondents state that they take into account these two factors.

\section{Benefits of Social Media Marketing}

Based on the responses of the owners/managers of the Café \& Resto companies, the benefits obtained from the use of social media marketing are summarized in Figure 1.

1. Communication with customers.

The highest benefit obtained by the Café and Resto companies from the use of social media marketing is the improvement of communication with customers. This statement is supported by 65 respondents. The content posted in social media, such as Facebook, Instagram, or Twitter might get responses from the users connected to the account. The users who want to get more information about a product or service can communicate directly through social media. The administrators can respond to various things that social media users want to know about the company.

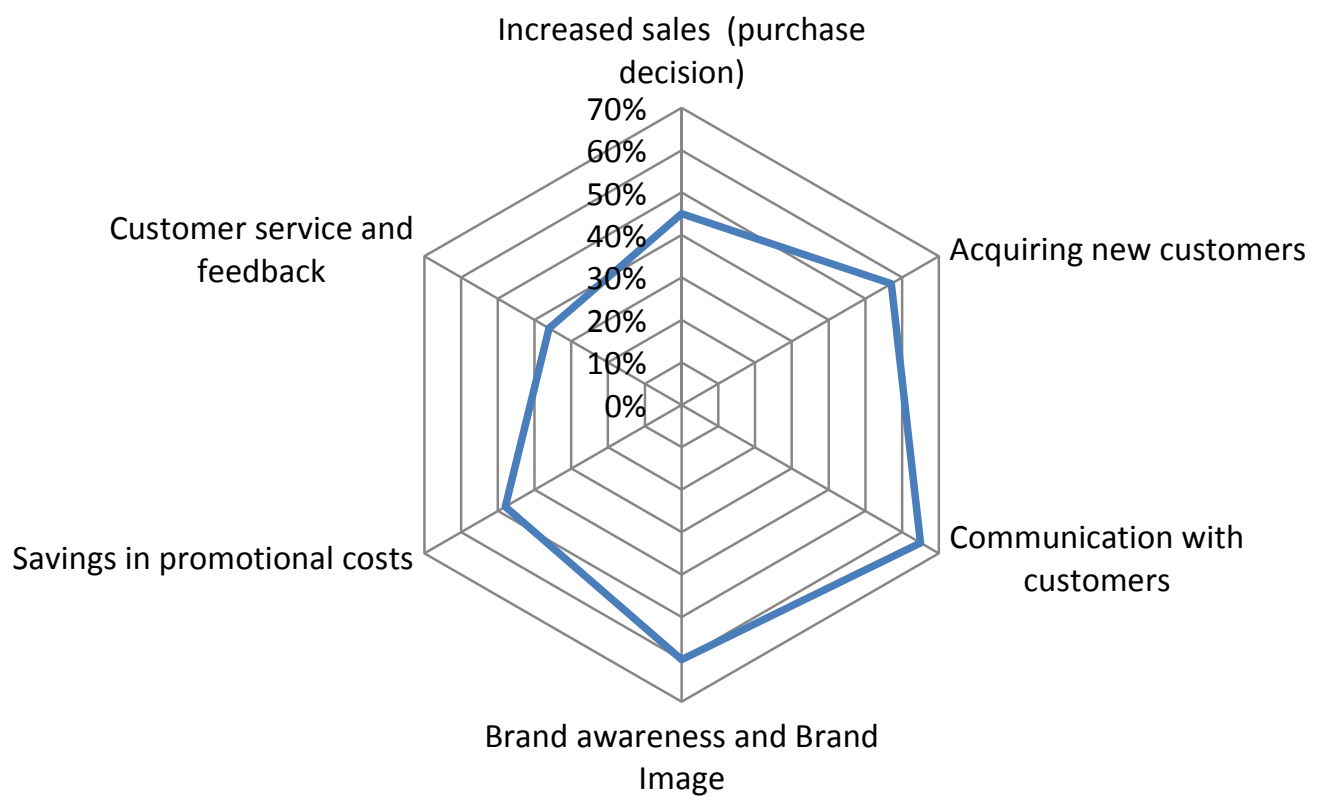

Figure 1. Benefits of Social Media Marketing

Source: Formed by authors 
One of the advantages of using social media is the opportunity to get the input from customers and to improve the customer experience (Jin, Muqaddam and Ryu, 2019). Moreover, social media allow interaction between consumers and a brand (Tsai and Men, 2013), as well as customer engagement (Tsimonis and Dimitriadis, 2014). Furthermore, interaction between consumers and companies will provide an advantage of being able to understand consumers, their desires and expectations. Interaction and understanding customers' needs and closeness to them are the goals of social media marketing (Andzulis, Panagopoulos and Rapp, 2012; Godey et al., 2016; Seo and Park, 2018). These findings explain the fact that more effective interaction with customers through social media marketing is one of the reasons for the use of social media marketing.

2. Brand Awareness and Brand Image.

The next highest benefit, according to $65 \%$ of Café \& Resto companies owners, is that the use of social media can increase brand awareness and brand image (brand equity). Social media marketing can increase customer awareness about the existence of Café \& Resto companies, understand the products and services that are characteristic of a certain Café \& Resto companies. These characteristics might create the brand image and increase the brand popularity.

The nature of social media users is the occurrence of communication in the user community. They will share content with the connected community, provide recommendations among users. Likewise, the content in social media posted by a Café \& Resto company will be shared by one or more social media users with their social communities. Thus, social media marketing will increase brand awareness. This result support prior studies that social media marketing will affect brand awareness (Lim, Chung and Weaver, 2012; Hutter et al., 2013; Tsimonis and Dimitriadis, 2014; Barreda et al., 2015; Bilgin, 2018).

3. Acquiring new customers.

The level of competition in Café \& Resto sector has been relatively high in recent years. Thus, attracting consumers has become a hard task for marketers. Social media marketing turns out to be able to carry out its function of attracting new customers and this is the third highest goal (57\%) of social media marketing activities at cafés and restaurants. The use of social media provides benefits for businesses since they are able to reach more people. The benefit for the brand is that it can be targeted at a certain social group or community (Tsimonis and Dimitriadis, 2014).

4. Savings on promotional costs.

Respondents acknowledge that one of the benefits obtained from social media marketing is the ability to save on promotional costs, compared to promotion in other media. Tsimonis and Dimitriadis (2014) suggest that one of the goals of using social media is to reduce promotional costs. Social media such as Instagram, Facebook, and Twitter provide options for users to have a personal account (free of charge) or a business (paid) account. Personal accounts tend to function for business to customers (B2C) activities, while business accounts are for business to business (B2B) activities. If social media marketing is focused on customer relations and promotion, personal accounts are still able to carry out their functions. The only weakness of a personal account is its credibility compared to the use of a business account, with an annual fee that is not large compared to promoting via other electronic media.

5. Increased sales (customer intention and customer decision).

The objective of promotional activities is to achieve sales growth; likewise, the social media marketing used by Café \& Resto companies can increase sales. Posting content in social media will spread to various social communities, and encourage them to come or visit a café or restaurant, especially if a Café \& Resto company is unique and the place is Instagrammable. This finding supports previous studies that social media contribute to marketing and sales activities (Jalilvand and Samiei, 2012; Hudson and Thal, 2013; Hutter et al., 2013; Lin, 2013; Goodrich and De Mooij, 2014; Ardiansyah and Sarwoko, 2020).

6. Handling complaints (customer service and feedback).

Café \& Resto is a business that does not only rely on taste but also on quality of service. 
Nurfarida, I. N. and Sudarmiatin (2021), "Use of social media marketing in SMEs: driving factors and impacts", Management and entrepreneurship: trends of development, 2(16), pp. 70-81. Available at: https://doi.org/10.26661/2522-1566/2021-1/16-06.

Positive or negative responses related to products and services will usually be posted by users in connected social media. A negative response (negative review) will be an advantage for the Café \& Resto as an evaluation material or an opportunity to provide feedback.

\section{CONCLUSION}

The development of social media requires business people, especially small businesses to adapt their marketing activities. Social media marketing is one of the commonly adopted marketing strategies. The main consideration of cafes and restaurants in utilizing social media marketing is to introduce products to consumers, due to the fact that the majority of consumers are social media users, to increase the popularity of businesses, to post information to consumers. Other reasons for the social media marketing development are its use by competitors and its low cost. The main benefits obtained from the use of social media marketing at Café \& Resto SMEs are increased communication with customers, brand awareness and brand image, acquisition of new customers, savings in promotion costs, increased sales and ability to handle complaints (customer service and feedback).

This study provides theoretical implications for developing new marketing strategies, such as social media marketing. Therefore, its effectiveness still needs to be further explored. As for practical contributions, the findings of this study recommend that small businesses must be adaptive to environmental and technological changes. Changing the consumer behavior must be accompanied by the ability of businesses to understand the consumer wants and needs. Social media is able to provide solutions to these needs since a company can organize the two-way communication with consumers using social media.

This study has the limitation for it has only explored social media marketing activities of Café and Resto SMEs. The research on a wider scope is needed to obtain more precise results. Furthermore, future research can also be conducted using comparative studies on the role of each social medium (Facebook, Instagram, Twitter) in marketing results.

\section{REFERENCES}

Andzulis, J. "Mick", Panagopoulos, N. G. and Rapp, A. (2012), "A review of social media and implications for the sales process", Journal of personal selling \& sales management, 32(3), pp.305-316. Available at: http://dx.doi.org/10.2753/pss0885-3134320302.

Ardiansyah, F. and Sarwoko, E. (2020), "How social media marketing influences consumers purchase decision: A mediation analysis of brand awareness", JEMA: Jurnal Ilmiah Bidang Akuntansi dan Manajemen, 17(2), pp. 156-168. Available at: http://dx.doi.org/10.31106/jema.v17i2.6916.

Barreda, A. A. et al. (2015), "Generating brand awareness in Online Social Networks", Computers in Human Behavior, 50, pp. 600-609. Available at: http://dx.doi.org/10.1016/j.chb.2015.03.023.

Bilgin, Y. (2018), "The effect of social media marketing activities on brand awareness, brand image and brand loyalty", Business \& Management Studies: An International Journal, 6(1), pp. 128148. Available at: http://dx.doi.org/10.15295/bmij.v6i1.229.

Binienda, N. J. (2016), "Transformational advertising via Instagram and its impact on expected happiness and willingness-to-pay", Erasmus University Rotterdam, Business Economics. Available at: https://thesis.eur.nl/pub/36917 (Accessed 20 March 2021).

Brogan, C. (2010), Social media 101: Tactics and tips to develop your business online, John Wiley \& Sons. Available at: http://dx.doi.org/10.1002/9781118256138.

Buttle, F. and Maklan, S. (2019), Customer relationship management concepts and technologies, Fourth Ed., New York : Routledge. 
Chaffey, D. (2015), Digital Business and E-Commerce Management: Strategy, Implementation and Practice, New York : Pearson Education Limited.

Chen, A., Lu, Y. and Wang, B. (2017), 'Customers' purchase decision-making process in social commerce: A social learning perspective', International Journal of Information Management, 37(6), pp.627-638. Available at: http://dx.doi.org/10.1016/j.ijinfomgt.2017.05.001.

Christina, I. D., Fenni, F. and Roselina, D. (2019), "Digital marketing strategy in promoting product", Management and Entrepreneurship: Trends of Development, 4(10), pp. 58-66. Available at: http://dx.doi.org/10.26661/2522-1566/2019-4/10-05.

Cooper, D. R., Schindler, P. S. and Sun, J. (2006), Business research methods, Mcgraw-hill New York.

Dahnil, M. I. et al. (2014), "Factors influencing SMEs adoption of social media marketing", Procedia - Social and Behavioral Sciences, 148, pp.119-126. Available at: http://dx.doi.org/10.1016/j.sbspro.2014.07.025.

Durkin, M., McGowan, P. and McKeown, N. (2013), "Exploring social media adoption in small to medium-sized enterprises in Ireland", Journal of Small Business and Enterprise Development, 20(4), pp.716-734. Available at: http://dx.doi.org/10.1108/jsbed-08-2012-0094.

Elwalda, A. and Lu, K. (2016), "The impact of online customer reviews (OCRs) on customers' purchase decisions: An exploration of the main dimensions of OCRs", Journal of Customer Behaviour, 15(2), pp. 123-152. Available at: https://doi.org/10.1362/147539216x14594362873695.

Garrido-Moreno, A. et al. (2020), "Social Media use and value creation in the digital landscape: a dynamic-capabilities perspective", Journal of Service Management, 31(3), pp.313-343. Available at: http://dx.doi.org/10.1108/josm-09-2018-0286.

Godey, B. et al. (2016), "Social media marketing efforts of luxury brands: Influence on brand equity and consumer behavior", Journal of Business Research, 69(12), pp.5833-5841. Available at: http://dx.doi.org/10.1016/j.jbusres.2016.04.181.

Goodrich, K. and De Mooij, M. (2014), "How 'social' are social media? A cross-cultural comparison of online and offline purchase decision influences", Word of Mouth and Social Media, pp.114-127. Available at: http://dx.doi.org/10.4324/9781315776279-12.

Guesalaga, R. (2016), "The use of social media in sales: Individual and organizational antecedents, and the role of customer engagement in social media", Industrial Marketing Management, 54, pp.71-79. Available at: http://dx.doi.org/10.1016/j.indmarman.2015.12.002.

Hudson, S. and Thal, K. (2013), "The Impact of Social Media on the Consumer Decision Process: Implications for Tourism Marketing", Journal of Travel \& Tourism Marketing, 30(1-2), pp.156-160. Available at: http://dx.doi.org/10.1080/10548408.2013.751276.

Hutter, K. et al. (2013), "The impact of user interactions in social media on brand awareness and purchase intention: The case of MINI on Facebook", Journal of Product \& Brand Management, 22(5/6), pp.342-351. Available at: http://dx.doi.org/10.1108/jpbm-05-20130299.

Ismail, A. R. (2017), "The influence of perceived social media marketing activities on brand loyalty: The mediation effect of brand and value consciousness", Asia Pacific Journal of Marketing and Logistics, 29(1), pp. 129-144. Available at: http://dx.doi.org/10.1108/apjml10-2015-0154.

Jalilvand, M. R. and Samiei, N. (2012), "The effect of electronic word of mouth on brand image and purchase intention", Marketing Intelligence \& Planning, 30(4), pp.460-476. Available at: http://dx.doi.org/10.1108/02634501211231946.

Jin, S. V., Muqaddam, A. and Ryu, E. (2019), "Instafamous and social media influencer marketing”, Marketing Intelligence \& Planning, 37(5), pp.567-579. Available at: http://dx.doi.org/10.1108/mip-09-2018-0375.

Kaplan, A. M. and Haenlein, M. (2010), "Users of the world, unite! The challenges and 
Nurfarida, I. N. and Sudarmiatin (2021), "Use of social media marketing in SMEs: driving factors and impacts", Management and entrepreneurship: trends of development, 2(16), pp. 70-81. Available at: https://doi.org/10.26661/2522-1566/2021-1/16-06.

opportunities of Social Media", Business Horizons, 53(1), pp.59-68. Available at: http://dx.doi.org/10.1016/j.bushor.2009.09.003.

Kim, A. J. and Ko, E. (2012), "Do social media marketing activities enhance customer equity? An empirical study of luxury fashion brand", Journal of Business Research, 65(10), pp.14801486. Available at: http://dx.doi.org/10.1016/j.jbusres.2011.10.014.

Kozinets, R. V et al. (2010), "Networked narratives: Understanding word-of-mouth marketing in online communities", Journal of Marketing, 74(2), pp.71-89. Available at: http://dx.doi.org/10.1509/jmkg.74.2.71.

Kristina, T. and Sugiarto, C. (2020), "The role of trust mediates in the influence of social media marketing and Electronic Word-of-Mouth on purchase intention", Management and Entrepreneurship: Trends of Development, 4(14), pp. 102-113. Available at: http://dx.doi.org/10.26661/2522-1566/2020-4/14-08.

Langaro, D., Rita, P. and de Fátima Salgueiro, M. (2018), "Do social networking sites contribute for building brands? Evaluating the impact of users' participation on brand awareness and brand attitude", Journal of Marketing Communications. Routledge, 24(2), pp. 146-168. Available at: https://doi.org/10.1080/13527266.2015.1036100.

Lim, Y., Chung, Y. and Weaver, P. A. (2012), "The impact of social media on destination branding: Consumer-generated videos versus destination marketer-generated videos", Journal of Vacation Marketing, 18(3), pp.197-206. Available at: http://dx.doi.org/10.1177/1356766712449366.

Lin, Y. (2013), "Evaluation of co-branded hotels in the Taiwanese market: the role of brand familiarity and brand fit", International Journal of Contemporary Hospitality Management, 25(3), pp.346-364. Available at: http://dx.doi.org/10.1108/09596111311311017.

Magasic, M. (2016), "The "Selfie Gaze" and "Social Media Pilgrimage": Two Frames for Conceptualising the Experience of Social Media Using Tourists", Information and Communication Technologies in Tourism 2016, pp.173-182. Available at: http://dx.doi.org/10.1007/978-3-319-28231-2_13.

Malangtimes (2019), Sektor kuliner menjamur di Kota Malang, Penelitian BI: sutainability masih kurang. Available at: https://www.malangtimes.com/baca/40284/20190606/073000/sektorkuliner-menjamur-di-malang-penelitian-bi-sustainability-masih-kurang (Accessed 20 March 2021), (in Indonesian).

Marshall, G. W. et al. (2012), "Revolution in Sales: The Impact of Social Media and Related Technology on the Selling Environment", Journal of Personal Selling \& Sales Management, 32(3), pp.349-363. Available at: http://dx.doi.org/10.2753/pss0885-3134320305.

Quinn, K. (2016), "Why we share: A uses and gratifications approach to privacy regulation in social media use", Journal of Broadcasting \& Electronic Media, 60(1), pp.61-86. Available at: http://dx.doi.org/10.1080/08838151.2015.1127245.

Schultz, D. E. and Peltier, J. J. (2013), "Social media's slippery slope: challenges, opportunities and future research directions", Journal of Research in Interactive Marketing, 7(2), pp. 86-99. Available at: https://doi.org/10.1108/jrim-12-2012-0054.

Seo, E.-J. and Park, J.-W. (2018), "A study on the effects of social media marketing activities on brand equity and customer response in the airline industry", Journal of Air Transport Management, 66, pp.36-41. Available at: http://dx.doi.org/10.1016/j.jairtraman.2017.09.014.

Thoring, A. (2011), "Corporate Tweeting: Analysing the Use of Twitter as a Marketing Tool by UK Trade Publishers”, Publishing Research Quarterly, 27(2), pp.141-158. Available at: http://dx.doi.org/10.1007/s12109-011-9214-7.

Tsai, W.-H. S. and Men, L. R. (2013), "Motivations and Antecedents of Consumer Engagement With Brand Pages on Social Networking Sites", Journal of Interactive Advertising, 13(2), pp.76-87. Available at: http://dx.doi.org/10.1080/15252019.2013.826549. 
Tsimonis, G. and Dimitriadis, S. (2014), "Brand strategies in social media", Marketing Intelligence \& Planning, 32(3), pp.328-344. Available at: http://dx.doi.org/10.1108/mip-04-2013-0056.

Tuten, T. L. (2020), Social Media Marketing, Singapore : SAGE Publications.

Wahyudi, I. (2019), "Segmen Merata, Apkrindo Yakin Pertumbuhan Kafe Berbasis Kopi Meningkat", RRI Malang. Available at: https://m.rri.co.id/malang/ekonomiperbankan/730573/segmen-merata-apkrindo-yakin-pertumbuhan-kafe-berbasis-kopimeningkat (Accessed 20 March 2021), (in Indonesian).

\section{ВИКОРИСТАННЯ МАРКЕТИНГУ СОЦАЛЬНИХ МЕДІА В МСП: ФАКТОРИ ВПЛИВУ}

\author{
Iva Nurdiana Nurfarida \\ Universitas Negeri Malang \\ Indonesia
}

\author{
Sudarmiatin \\ Universitas Negeri Malang \\ Indonesia
}

Це дослідження спрямоване на вивчення факторів, що стимулюють використання маркетингу в соціальних мережах у секторі Café \& Resto, а також на виявлення його переваг. За допомогою описового дослідницького підходу було проведено онлайн-опитування в секторі Café \& Resto в місті Маланг, Індонезія. Зразки були відібрані за допомогою зручної методики вибірки, респондентів попросили заповнити форму Google, яка була надіслана на їхні адреси в соціальних мережах. Всього через їхні акаунти через соціальні мережі було встановлено контакт із 300 кафе та ресторанами, що відповідало 106 респондентам. Результати показали, що основними факторами, які розглядають компанії Café \& Resto при виборі маркетингу в соціальних мережах, було представлення продуктів споживачам, оскільки більшість споживачів були користувачами соціальних мереж, збільшення популярності бізнесу та обмін інформацією зі споживачами. Додатковими факторами $є$ заохочення конкурентів, які також використовують соціальні мережі, та низька вартість. Основними перевагами, отриманими від використання маркетингу в соціальних мережах, $\epsilon$ збільшення комунікації з клієнтами, поінформованість про бренд та імідж бренду, залучення нових клієнтів, економія на рекламних витратах, збільшення продажів та здатність управляти невдоволенням (обслуговування клієнтів та зворотній зв'язок). Це дослідження має обмеження - кількість респондентів, які беруть участь, необхідні подальші дослідження на більш широкій вибірці. Крім того, подальші дослідження можуть бути розроблені шляхом перевірки ефективності використання кожного каналу соціальних мереж, оскільки кожен канал соціальних мереж має різні характеристики та цілі користувачів.

Ключові слова: маркетинг у соціальних мережах, комунікація 3 клієнтами, проінформованість про бренд.

\section{ИСПОЛЬЗОВАНИЕ МАРКЕТИНГА СОЦИАЛЬНЫХ СЕТЕЙ В МСП: ФАКТОРЫ ВЛИЯНИЯ}

\author{
Iva Nurdiana Nurfarida \\ Universitas Negeri Malang \\ Indonesia
}

\author{
Sudarmiatin \\ Universitas Negeri Malang \\ Indonesia
}

Это исследование направлено на изучение факторов, стимулирующих использование маркетинга в социальных сетях в секторе Café \& Resto, а также на выявление его преимуществ. С помощью описательного исследовательского подхода был проведен онлайнопрос в секторе Café \& Resto в городе Маланг, Индонезия. Образцы были отобраны с 
Nurfarida, I. N. and Sudarmiatin (2021), "Use of social media marketing in SMEs: driving factors and impacts", Management and entrepreneurship: trends of development, 2(16), pp. 70-81. Available at: https://doi.org/10.26661/2522-1566/2021-1/16-06.

помощью удобной методики выборки, респондентов попросили заполнить форму Google, которая была направлена на их адреса в социальных сетях. Всего через их аккаунты через социальные сети был установлен контакт с 300 кафе и ресторанами, что соответствовало 106 респондентам. Результаты показали, что основными факторами, которые рассматривают компании Café \& Resto при выборе маркетинга в социальных сетях, было представление продуктов потребителям, поскольку большинство потребителей были пользователями социальных сетей, увеличение популярности бизнеса и обмен информацией с потребителями. Дополнительными факторами являются поощрение конкурентов, которые также используют социальные сети, и низкая стоимость. Основными преимуществами, полученными от использования маркетинга в социальных сетях, является увеличение коммуникации с клиентами, осведомленность о бренде и имидж бренда, привлечение новых клиентов, экономия на рекламных расходах, увеличение продаж и способность управлять недовольством (обслуживание клиентов и обратная связь). Это исследование имеет ограничение - количество респондентов, необходимы дальнейшие исследования на более широкой выборке. Кроме того, дальнейшие исследования могут быть разработаны путем проверки эффективности использования каждого канала социальных сетей, поскольку каждый канал социальных сетей имеет различные характеристики и цели пользователей.

Ключевые слова: маркетинг в социальных сетях, коммуникация с клиентами, осведомленность о бренде. 